\title{
Dampak Kadmium terhadap Kadar Glukosa Hepar Tikus Putih (Rattus norvegicus) in vitro
}

\author{
Valentina Halim ${ }^{1}$, Eko Suhartono ${ }^{2 *}$, Agung Biworo ${ }^{3}$ \\ Program Studi Pendidikan Dokter ${ }^{1}$ \\ Departemen Biokimia dan Biologi Molekuler ${ }^{2}$ \\ Departemen Farmakologi ${ }^{3}$ \\ Fakultas Kedokteran Universitas Lambung Mangkurat Banjarmasin. \\ *e-mail: ekoantioxidant@gmail.com
}

\begin{abstract}
Abstrak
Mekanisme kadmium menginduksi toksisitas pada hepar yaitu dengan menimbulkan stres oksidatif. Stres oksidatif menghambat enzim yang berperan dalam proses metabolisme glukosa. Penelitian ini bertujuan untuk menganalisis perbedaan kadar glukosa pada homogenat hepar. Penelitian ini merupakan penelitian eksperimental laboratorik yang dilakukan pada 4 kelompok: kelompok P0 yang tidak dipajankan $\mathrm{Cd}$, kelompok P1 dipajankan $\mathrm{Cd}$ 0,03 mg/L, kelompok P2 dipajankan Cd 0,3 mg/L, dan kelompok P3 dipajankan Cd $3 \mathrm{mg} / \mathrm{L}$. Hasil penelitian didapatkan rata-rata kadar glukosa pada kelompok P0 sebesar $21.667 \mu \mathrm{M}$, kelompok P1 sebesar $33.278 \mu \mathrm{M}$, kelompok P2 sebesar $69.889 \mu \mathrm{M}$, dankelompok P3 sebesar $150.667 \mu \mathrm{M}$. M elalui uji statistik Kruskal-Wallis didapatkan perbedaan yang bermakna $p=0,000$ $(p \varangle, 05)$ dan uji pos hoc Mann-Whitney juga menunjukkan perbedaan yang bermakna pada semua kelompok. Dapat disimpulkan bahwa semakin tinggi kepekatan/konsentrasi pemajanan $\mathrm{Cd}$ terhadap homogenat heparmaka semakin tinggi pula peningkatan kadar glukosa pada hepar tikus.
\end{abstract}

Kata kunci: kadmium, glukosa, hepar

\section{Cadmium Impact on Liver Glucose Level in White Rat (Rattus norvegicus) in vitro}

\begin{abstract}
The mechanism of cadmium inducing hepatotoxicity is by creating oxidative stress. Oxidative stress inhibits enzymes which have a role in the process of glucose metabolism. This research aimed to analyze the diffferences of glucose level in the liver homogenate. This research was an experimental laboratory using four groups namely $\mathrm{P} 0$ group unexposed to $\mathrm{Cd}, \mathrm{P} 1$ group exposed to $\mathrm{Cd} 0,03 \mathrm{mg} / \mathrm{L}$, P2 group exposed to $\mathrm{Cd} 0,3 \mathrm{mg} / \mathrm{L}$, and P3 group exposed to $\mathrm{Cd} 3$ $\mathrm{mg} / \mathrm{L}$. The result showed the average levels of glucose in P0 group was $21.667 \mu \mathrm{M}, \mathrm{P} 1$ group was $33.278 \mu \mathrm{M}, \mathrm{P} 2$ group was $69.889 \mu \mathrm{M}$, and P3 group was150.667 $\mu \mathrm{M}$. Statistical analysis Kruskal-Wallis test found significant differences $p=0,000(p<0,05)$ and post hoc test using Mann-Whitney also showed significant differences in all groups. It can be concluded that the higher $\mathrm{Cd}$ concentration exposed to liver homogenate the higher elevation levels of glucose in the rat liver.
\end{abstract}

Keywords: cadmium, glucose, liver 
Dampak Kadmium terhadap Kadar Glukosa Hepar Tikus Putih (Rattus norvegicus) in vitro Valentina Halim, Eko Suhartono, Agung Biworo

\section{PENDAHULUAN}

Kadmium (Cd) merupakan salah satu jenis logam berat yang banyak dimanfaatkan untuk kehidupan manusia. Misalnya: senyawa CdS dan CdSeS banyak digunakan sebagai zat warna, $\mathrm{CdSO}_{4}$ digunakan dalam industri baterai yang berfungsi untuk pembuatan sel Weston, $\mathrm{CdBr}_{2}$ dan $\mathrm{Cdl}_{2}$ yang secara terbatas digunakan dalam dunia fotografi, $\quad\left(\mathrm{C}_{2} \mathrm{H}_{5}\right)_{2} \mathrm{Cd}$ digunakan dalam mekanisme pembuatan tetraetil-Pb, dan masih banyak lagi (Cotuk dkk, 2010; Iskandar dkk, 2017). Selain bermanfaat, Cd juga merupakan polutan yang dapat merusak lingkungan sehingga terakumulasi didalamnya.

Berdasarkan hasil beberapa penelitian yang dilakukan oleh Komari dkk (2013) di perairan sekitar Pelabuhan Trisakti Banjarmasin Kalimantan Selatan ditemukan kandungan $\mathrm{Cd}$. Adapun temuan $\mathrm{Cd}$ yang ditemukan sebagai berikut : di daerah perairan Basirih sebesar 0,034 ppm, Trisakti sebesar 0,03 ppm, dan Banjar Raya sebesar 0,029 ppm. Hal ini menunjukkan bahwa kadar Cd pada daerah tersebut sudah melewati baku mutu yang ditetapkan oleh Keputusan Gubernur Kalimantan Selatan No.5 Tahun 2007, yaitu kandungan logam berat kadmium tidak boleh melebihi 0,01 ppm pada suatu perairan.

Kadmium dapat masuk kedalam tubuh manusia melalui saluran pencernaan, paru- paru, dan kulit. Setelah memasuki sistem peredaran darah, $\mathrm{Cd}$ akan berikatan dengan sel darah merah dan protein yang memiliki berat molekul tinggi dalam plasma, khususnya oleh albumin. Selanjutnya Cd masuk ke dalam hepar untuk proses detoksifikasi. Di dalam hepar, Cd berikatan dengan protein yang memiliki berat molekul rendah, yakni metallothionein dan kemudian membentuk kompleks Cd-metallothionein. Kompleks Cd-metallothionein akan diangkut ke dalam membran sinusoid hepar dan dipecah ikatannya. Sebagian kadmium akan memasuki siklus entero-hepatik dan berikatan dengan Cd-glutation untuk dikeluarkan dari tubuh melalui sistem bilier. Sebagian lainnya akan tetap berada di hepar dan terakumulasidi dalamnya (Bernard dkk, 2008).

Akumulasi Cd di hepar akan menginduksi terbentuknya stres oksidatif, seperti superoksida $\left(\mathrm{O}_{2}{ }^{\circ}\right)$, senyawa hidroksil $\left(\mathrm{OH}^{*}\right)$, nitrit oksida $(\mathrm{NO})$, dan hidrogen peroksida $\left(\mathrm{H}_{2} \mathrm{O}_{2}\right)$ melalui reaksi fenton. Superoksida $\left(\mathrm{O}_{2}{ }^{\circ}\right)$, senyawa hidroksil $\left(\mathrm{OH}^{\bullet}\right)$, dan hidrogen peroksida $\left(\mathrm{H}_{2} \mathrm{O}_{2}\right)$ yang terbentuk akan menyebabkan hepatotoksisitas yang ditandai oleh degenerasi sel hepar, gangguan biomarker fungsi hati, dan gangguan sintesis enzim yang berperan dalam metabolisme glukosa (Adikwu, 2013; Gill, 2014; Anindya, 2016). 
Penelitian oleh Cicik (2005) sentrifuge (SENTURION ${ }^{\circledR}$ ), waterbath, menyatakan bahwa hewan coba yang timbangan, jarum suntik, spektrofotomoter diinduksi $\mathrm{Cd}$ menyebabkan peningkatan $\left(\mathrm{T} 80+{ }^{\circledR}\right)$, mikropipet (Clinipet $\left.{ }^{\mathbb{Q}}\right)$, sarung kadar glukosa dalam darah dan penurunan tangan, neraca elektrik (GIBERTINI ${ }^{\circledR}$ ), alat kadar glikogen pada hepar. Penelitian lain bedah minor, dan kandang tikus.

juga melaporkan bahwa induksi $\mathrm{Cd}$ berhubungan dengan peningkatan kadar $\mathrm{HbAlc}$ dalam darah pasien diabetes mellitus (Borne, 2014). Penelitian tentang pengaruh pajanan Cd terhadap kadar glukosa sudah banyak dilakukan terkait darah manusia dan hewan coba, tetapi belum banyak yang meneliti pengaruhnya pada hepar. Oleh karena itu, penelitian ini akan mengkaji perubahan kadar glukosa pada hepar akibat induksi $\mathrm{Cd}$.

\section{BAHAN DAN METODE}

Rancangan penelitian yang digunakan adalah studi eksperimental dengan posttestonly with control group design.Subjek penelitian adalah tikus putih (Rattus norvegicus) jantan sebanyak 24 ekor berumur sepuluh minggu dan berat 200-250 gram dibagi menjadi 4 kelompok masingmasing 6 ekor. Bahan-bahan yang digunakan pada penelitian ini, antara lain hepar tikus putih (Rattus norvegicus) jantan, aquadest, $\mathrm{CdSO}_{4}$ yang dilarutkan, glukosa, ketamin, buffer fosfat pH 7, Trikloro Asetat (TCA) 20\%, fenol $3 \%$, dan $\mathrm{H}_{2} \mathrm{SO}_{4}$ pekat.Alat-alat yang digunakan pada penelitian meliputi gelas kimia(PYREX $\left.{ }^{\circledR}\right)$ gelas beker $\left(\right.$ Iwaki $\left.^{\circledR}\right)$, spuit,

\section{Pembuatan homogenat}

Tikus putih diperoleh dari peternakan tikus di Samarinda. Tikus putih diaklimatisasi selama satu minggu untuk memberikan kondisi fisik dan psikologis yang sama. Selajutnya tikus putih dikorbankan dengan menggunakan ketamin serta dilakukan pembedahan untuk diambil heparnya. Hepar dicuci dengan TCA 20\% lalu difiksasi dalam larutan buffer fosfat pH 7 dan ditumbuk hingga berubah menjadi cairan (homogenat). Homogenat hepar dibagi sesuai perlakuan (Kania, 2016; Lestarisa, 2016).

\section{Perlakuan homogenat}

Homogenat hepar kemudian diberi perlakuan sesuai dengan kelompok uji, yakni: kelompok homogenat POhomogenate kontrol (tanpa perlakuan); P1= kelompok homogenat dipajankan 0,003 mg/L $\mathrm{CdSO}_{4}$; P2=kelompok homogenat yang dipajankan 0,3 mg/ $\mathrm{L} \mathrm{CdSO}_{4} ; \mathrm{P} 3=$ kelompok homogenat yang dipajankan $3 \mathrm{mg} / \mathrm{L} \mathrm{CdSO}_{4}$. Semua kelompok diinkubasi selama satu jam. Setelah selesai diinkubasi, masing-masing homogenat kemudian disentrifugasi dengan kecepatan 3500 rpm selama 10 menit guna 
Dampak Kadmium terhadap Kadar Glukosa Hepar Tikus Putih (Rattus norvegicus) in vitro Valentina Halim, Eko Suhartono, Agung Biworo

mendapatkan supernatan. Supernatan kemudian diambil untuk diperiksa kadar glukosa.

\section{Pengukuran Glukosa (metode hidrolitik Dubois)}

Untuk mengukur glukosa homogenat dilakukan dengan mencampurkan $0,5 \mathrm{~mL}$ homogenat hepar dengan $0,7 \mathrm{~mL}$ fenol $3 \%$ dan $2 \mathrm{~mL} \mathrm{H} \mathrm{H}_{2} \mathrm{~S}_{4}$ pekat. Kemudian larutan diukur dengan spektrofotometer pada panjang gelombang $540 \mathrm{~nm}$ (Iskandar dkk, 2017).
HASIL

Hepar berperan penting dalam mempertahankan konsentrasi glukosa normal. Dalam metabolisme karbohidrat, hepar berfungsi sebagai tempat untuk menyimpan glikogen dalam jumlah besar. Selain itu, juga untuk memecah galaktosa dan fruktosa menjadi glukosa, tempat glukoneogenesis, dan membentuk banyak senyawa kimia dari produk antara metabolisme karbohidrat (Suhartono dkk, 2015). Hasil pengukuran glukosa disajikan pada Gambar 1.

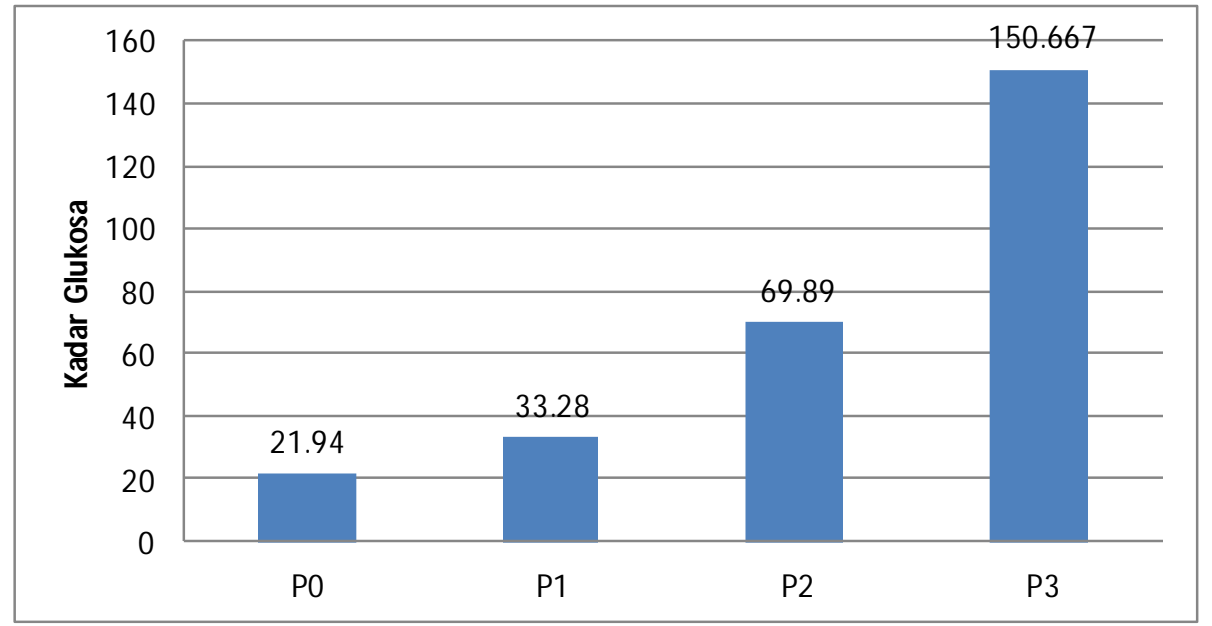

Gambar 1. Kadar glukosa hepar ( $\mu \mathrm{M})$ pada berbagai konsentrasi $\mathrm{Cd}$

Berdasarkan uji Kruskal-

Wallisdiperoleh $p=0,000(p<0,05)$. Uji lanjut Mann-Whitney menunjukkan perbedaan yang bermakna terhadap semua kelompok. $\mathrm{Hal}$ ini berarti pemberian $\mathrm{Cd}$ berbagai konsentrasi dapat meningkatkan kadar glukosa di hepar.

\section{PEMBAHASAN}

Pada penelitian ini glukosa hepar diperoleh dari pemecahan ikatan oligoglukosida dari glikogen oleh enzim amilase. Oligoglukosida kemudian dikatalisisis oleh enzim oligoglukosidase menjadi glukosa sehingga hasil akhirnya akan ditemukan glukosa pada hepar normal 
(Koyama, 2001; Suhartono, 2015). Penelitian ini juga mengungkapkan bahwa peningkatan konsentrasi $\mathrm{Cd}$ dapat menginduksi peningkatan kadar glukosa di hepar. Hal ini serupa dengan penelitian yang dilakukan oleh Sohba (2007) yang menyatakan bahwa kadar glukosa dapat meningkat pada organ hepar, otot, ginjal, dan jantung yang diinduksi $\mathrm{Cd}$. Penelitian lain yang dilakukan oleh Al Rikabi dan Jawad (2013) juga menyatakan bahwa induksi kadmium dapat meningkatkan kadar glukosa pada darah.

Gangguan metabolisme glukosa pada hepar akibat induksi $\mathrm{Cd}$ dapat diakibatkan oleh beberapa mekanisme. Mekanisme tersebut antara lain:

(a) Kadmium dapat menghambat aktivitas enzim fosfofruktokinase (PFK) pada jalur glikolisis sehingga terjadi penurunan glikolisis yang mengakibatkan glukosa menumpuk di dalam sel karena tidak bisa diubah menjadi piruvat dan laktat Almeida, 2001).

(b) Cd dapat meningkatkan kadar kortisol plasma secara signifikan, yang akan meningkatkan kadar glukosa. Peningkatan kadar glukosa ini, kemudian akan meningkatkan aktivitas glikogenolisis dan glikogen yang tersimpan di dalam hepar akan dipecah menjadi glukosa-6-fosfat, kemudian menjadi glukosa. Pemecahan glikogen secara terus-menerus mengakibatkan terjadinya penurunan pembentukan glikogen oleh glukosa sehingga kadar glukosa meningkat (Zahedi, 2012).

(c) Kadmium menghambat aktivitas glukosa-6-fosfat dehidrogenase (G6PD) sehingga oksidasi glukosa dan kadar laktat akan meningkat. Peningkatan kadar laktat ini juga terjadi karena terjadi karena kadmium menghambat aktivitas enzim laktat dehidrogenase (LDH) sehingga pemecahan glukosa menjadi piruvat menurun. Hasil akhirnya didapatkan glukosa yang meningkat (Carattino, 2004).

(d) Cd dapat berikatan dengan gugus sulfihifril (-SH) yang terdapat dalam $\mathrm{Na}^{+}$glukosa kotransporter 1, yakni protein pembawa glukosa sehingga terjadi perubahan pada struktur protein tersebut. Perubahan struktur ini berakibat pada berkurangnya aktivitas protein pembawa glukosa sehingga glukosa akan meningkat dan tertumpuk pada ekstrasel (Xiaobing, 2005).

\section{KESIMPULAN}

Berdasarkan uji Kruskal Wallis terdapat perbedaan antar kelompok yang signifikan $(p=0,000)$ terhadap peningkatan kadar glukosa hepar tikus putih (Rattus norvegicus) in vitro yang diinduksi oleh $\mathrm{Cd}$ pada konsentrasi yang berbeda. 
Dampak Kadmium terhadap Kadar Glukosa Hepar Tikus Putih (Rattus norvegicus) in vitro

Valentina Halim, Eko Suhartono, Agung Biworo

\section{DAFTAR PUSTAKA}

Adikwu E, Deo O, Geoffrey OBP, 2013. Hepatotoxicity of cadmium and roles of mitigating agents. British Journal of Pharmacology and Toxicology. 4(6): 222-231

Al Rikabi AA, Jawad AADH, 2013. Protective effect of ethanolic ginger extract agains cadmium toxicity in male rabbits. Bas J Vet Res. 12(1): 13-29

Almeida JA, Novelli ELB, SilvaMDP, Junior RA, 2001. Environmental cadmium exposure and metabolic responses of the Nile tilapia, Oreochromis niloticus. Environmental Polution. 114: 169-175

Anindya, Muhyi R, Suhartono E, 2016. Risiko penyakit jantung koroner akibat pajanan kadmium melalui pengukuran kadar kolesterol dan circulating endothelial cells darah tikus putih. Berkala Kedokteran. 12(2): 153-163

Bernard A. 2008. Cadmium and its adverse effect on human health. Indian Journal of M edicine Research. 128: 557-564

Borne Y, Fagerberg B, Persson M, Sallsten G, Forsgard N, Hedblad B, et al. 2014. Cadmium exposure and incidence of diabetes mellitus-results from the malmo diet and cancer study. Plos One.9(11): 1-5.

Carattino MD, Peralta S, Coll CP, Naab F, Burlon A, Kreiner AJ, et al, 2004. Effects of long-term exposure to $\mathrm{Cu}^{2+}$ and $\mathrm{Cd}^{2+}$ on the pentose phosphate pathway dehydrogenase activities in the ovary of adult Bufo arenarum: possible role as biomarker for $\mathrm{Cu}^{2+}$ toxicity. Ecotoxicology and Environmental Safety. 57: 311-318
Cicik B, Engin K, 2005. The effects of cadmium on levels of glucose in serum and glycogen reserves in the liver and muscle tissues of Cyprinus carpio (L., 1758).Turk J Vet Anim Sci. 29: 113-11

Cotuk Y, Belivermis M, Kilic O, 2010. Environmental biology and pathophysiology of cadmium. IUFS Journal of Biology. 69(1): 1-5

Gill M. 2014. Heavy metal stress inplants: a review. International Journal. 2(6): 1043-55

Iskandar, Budianto WY, Suhartono E, 2017. Effect of cadmium exposure on increasing risk of diabetes melitus through the measurement of blood glucose level and liver glucokinase activity in rats. Berkala Kedokteran.13(2): 137-145

Kania N, Iskandar Thalib, Suhartono E, 2016. Chlorinative Index in Liver Toxicity Induced by Iron. International Journal of Pharmaceutical and Clinical Research. 8(9): 1300-1304

Komari N, Irawati U, Novita E., 2013. Kandungan kadmium dan seng pada ikan baung (Hemibagrus nemurus) di perairan Trisakti Banjarmasin Kalimantan Selatan. Sains dan Terapan Kimia. 7(1): 4249

Koyama I, Komine S, lino N, Hokari S, Igarashi S, Alpers DA, Komoda T, 2001. $\alpha$ Amylase expressed in human liver is encoded by the AMY-2B gene identified in tumorous tissues. Clinica Chimica Acta. 309: 73-83 
ISSN 1978-2071 (Print); ISSN 2580-5967 (Online)

Jurnal IImiah Kedokteran Wijaya Kusuma 7(2) : 189-195, September 2018

Lestarisa T, Alexandra FD, Jelita $\mathrm{H}$, Suhartono E, 2016. Myeloperoxidase as an Indicator of Liver Cells Inflammation Induced by M ercury. International Journal of Pharmaceutical and Clinical Research. 8(11): 1516-1521

Sobha K, Poornima A, Harini P, Veeraiah K, 2007. A study on biochemical changes in the fresh waterfish, Catla catla (Hamilton) exposed to the heavymetal toxicant cadmium chloride. Kathmandu University Journal of Science Engineering and Technology. 1(4): 1-11

Suhartono E, Iskandar, Santosa PB, 2015. Ameliorative effects of different parts of gemor (Nothaphoebe coriacea) on cadmium induced glucose metabolism alteration in vitro. Int J Pharm Pharm Sci. 7(11): $17-20$

Xiaobing X, Gang W, Yanchun P, Ming-Gene $T$, Jimmy J, Hongqing $F, 2005$. The endogenous CXXC motif governs the cadmium sensitivity of the renal $\mathrm{na}^{+} /$glucose co-transporter. Journal of the American Society of Nephrology. 16: 1257-1265

Zahedi S, M irvaghefi A, Rafati M, Mehrpoosh M, 2012. Cadmium accumulation and biochemical parameters in juvenile Persian sturgeon, Acipenser persicus, upon sublethal cadmium exposure. 12(3): 1-9 